\title{
Risks of investing in the Russian stock market: Lessons of the first decade ${ }^{*}$
}

\author{
Alexei Goriaev ${ }^{\dagger}$ and Alexei Zabotkin
}

August 2006

\begin{abstract}
The modern history of the Russian stock market has mirrored ups and downs of the country's transition as well as swings in investor perceptions. In this paper, we describe the evolution of the Russian stock market over its first decade, with particular attention to the risk factors driving stock returns. First, we analyze the development of the institutional infrastructure and dynamics of the market's size and liquidity measured by the number of listed and traded stocks, depositary receipts and IPOs as well as trading volume in the local stock exchanges and abroad. Then, we examine major political and economic events, which influenced the investor perceptions of the country risk and were reflected in stock prices. Finally, we carry out quantitative analysis of risk factors explaining considerable time and cross-sectional variation in Russian stock returns. We document a significant role of corporate governance, political risk, and macroeconomic risk factors, such as global equity markets performance, oil prices, and exchange rates, whose relative importance varied a lot over time.
\end{abstract}

Keywords: financial institutions, risk factors, Russian stock market.

* We would like to thank Christopher Granville, Jan Hanousek and participants at the XVII-th research conference at the New Economic School in October 2005, Global Institute China-Russia conference in December 2005, and workshop on Financial Market Development in the Central and Eastern European Countries in May 2006 for helpful comments. Vadim Cherepanov, Georgy Kartashov, and Konstantin Petrov provided valuable research assistance.

${ }^{\dagger}$ New Economic School, Nakhimovsky pr. 47, Moscow 117418, Russia. Phone: +7495 129 1700, fax: +7495 129 3722, e-mail: agoriaev@,nes.ru.

*Deutsche UFG, e-mail: azabotkin@ufg.com. 


\section{Introduction}

Emerging markets provide a unique real-world setting to test economic theories, in particular, the role of financial development for the country's economic success. The idea of financial markets contributing to economic growth dates back to Schumpeter (1911) and is supported by recent empirical evidence (e.g., King and Levine, 1993, Rajan and Zingales, 2003a). At the same time, financial development reflects economic, political, and sociological situation as well as legal and regulatory environment in the country (e.g., La Porta et al., 1997, Levine, 1999, Rajan and Zingales, 2003b). The dynamic interaction between evolving financial institutions and typically unstable local environment as well as global factors can say a lot about the nature of problems faced by the corporations, investors, and regulators in a developing country. This experience, even though not always successful, could be useful not only to other countries in transition, but also to the developed ones.

A large literature is devoted to the issues of risk and predictability, integration, and asset pricing in the emerging markets (e.g., Bekaert and Harvey, 1997, Claessens, Djankov, and Klingebiel, 2000, Garcia and Ghysels, 1998, Harvey, 1995). We will review below part of this literature devoted to the Central and Eastern European countries gradually recovering market economy after the communist past. Hanousek and Filer (2000) find in 1993-1999 almost no contemporaneous relation between stock returns in Poland, Hungary, and the Czech Republic and macroeconomic variables; yet demonstrate that these variables had predictive ability in the first two countries, interpreting this as a rejection of the semi-strong efficiency. Sokalska (2001) argues that comovement of equity indices in the Czech Republic, Hungary, and Poland in 19932000 may be due to the common shocks in the "international investor sentiment." Mateus (2004) finds that stock markets in Bulgaria, Cyprus, Estonia, Lithuania, Romania, and Hungary were sensitive to global risk factors such as interest rates, the world excess return, exchange and inflation rates, whereas local factors were more important for the Czech Republic, Latvia, Poland, and Slovenia during the 1997-2002 period. De Jong and de Roon (2005) show that expected returns in the emerging markets in Europe, Mideast, and Africa are affected mostly by the country's segmentation, whereas the regional segmentation seems to be more important for those in Asia and Far East. Several asset pricing studies of individual stocks in the emerging markets (e.g., Rouwenhorst, 1999, Barry et al., 2002) find results on size and value premiums similar to those in the developed markets (cf. Fama and French, 1998), whereas van der Hart, Slagter, and van Dijk (2003) report significant premiums for value, momentum, and earnings revisions effects, but find no significant evidence for size and liquidity effects.

The case of Russia is particularly interesting, as the country being once the leader of the Soviet block had to create the stock market in the midst of its transition from the planned system 
to the market economy, during the times of severe economic crisis. Starting from the scratch in late 1994, the Russian stock market has by now become one of the largest emerging markets in the world, with the total market capitalization over $\$ 600$ bln or $80 \%$ of GDP at the end of 2005 . This growth was driven both by the expansion in the number of stocks and by high returns. Currently, more than 250 Russian stocks are listed locally or abroad, the monthly trading volume is over $\$ 14 \mathrm{bln}$, and IPOs are booming. However, the market still suffers from many structural deficiencies, such as high concentration and low potential of diversification using local instruments.

The formal analysis of Russian stocks has been hindered so far by short history and small number of liquid instruments in the market. Therefore, most existing studies focus on Russian equity indices. Hall and Urga (2002) document the decreasing degree of the market inefficiency in 1995-2000. Anatolyev (2005) finds that the Russian stock market had highly unstable links with macroeconomic variables in 1995-2004; however, upon maturing it became more sensitive to global factors, such as U.S. stock market performance and interest rates. Lucey and Voronkova (2005) also demonstrate rising integration of the Russian equity market with developed markets, but not those from the CEE region, after the 1998 crisis. Among studies of individual stocks, Fedorov and Sarkissian (2000) find that the degree of international integration during the pre-crisis period differed across Russian stocks depending on their size and industry. Goriaev (2004) finds significant premiums for the country risk, corporate governance, size and currency risks in 2000-2004. Goriaev and Sonin (2005) argue that the effect of the Yukos affair for stock prices was mostly driven by such companies' characteristics as government ownership and transparency.

The objective of the current paper is to investigate the evolution of the Russian equity market over its first decade, with particular attention to the risk factors driving stock returns. In the first part of the paper, we analyze the development of the institutional infrastructure, dynamics of the market's size and liquidity, and summary statistics of stock returns. We document the market expansion in terms of diversity and liquidity, which was interrupted by the August 1998 government default crisis, and decline of the local quote-driven market (RTS). The impressive market performance over its first decade (average return over 50\% p.a.) was accompanied by considerable volatility, both in time and cross-sectional dimensions, which, however, has been on a downward trend since the 1998 crisis.

In the second part of the paper, we describe major political and economic events, which influenced the investors' perception of the country risk and were reflected in stock prices. The defining moments of Russia's transition over the past decade range from the 1996 re-election of President Yeltsin, which headed off the threat of a Soviet revanche while maintaining systemic 
stability, to the serious setbacks of which experienced investors in Russia need no reminding: the financial debacle of 1998 and, more recently, the destruction of Yukos.

Finally, we carry out quantitative analysis of risk factors driving Russian stock returns. Using the methodology employing linear regressions over a one-year rolling window, we document substantial variation in systematic risks, both in time and cross dimensions, during the sample period from 1996 to 2005. Our results demonstrate a strong relation between the Russian stock market and other emerging markets. Such macroeconomic factors as oil prices, exchange rates, and domestic liquidity make an additional impact on Russian stock returns. The proposed multi-factor model explains up to half of their total variation in 2005.

The structure of the remainder of the paper is as follows. In Section 2, we describe the evolution of the Russian equity market in terms of size and liquidity and discuss its summary statistics characterizing the risk-return trade-off. Section 3 describes how key economic and political events in Russia and abroad influenced the Russian equity market. In section 4, we perform quantitative analysis of the risk factors driving Russian stock returns. Section 5 concludes.

\section{Description of the Russian stock market development}

\subsection{Dynamics of the market's size and liquidity}

The first trades in Russian stocks were executed in late 1994 as the initial phase of Russia's mass privatization was drawing to a close. It took until summer 1995 for the first centralized exchange, the Russian Trading System (RTS), to emerge in the form of a dealership market. However, it was the launch of the RTS index (RTSI) on 1 September 1995, which put the Russian stock market on the radar screens of the investing public at large (see the first panel of Table 1 for the summary statistics of the RTSI and Fig. 1 for its dynamics).

The universe of Russian stocks was always fairly large in terms of its sheer number, given that the privatization of the early 1990s instantly created numerous joint stock companies. During the 1997 bull market most of those were listed on the RTS exchange, thus there were more than 300 listed stocks in Russia by early 1998 (see Fig. 2). The financial crisis and resulting decline in market activity led to a contraction in this number to just below 200 by mid-1999, however, by 2001 it had climbed to a new high of over 350. The MICEX, an order-driven market, due to its later launch in 1997 and more stringent listing rules had around 170 stocks listed by then. The restructuring of the telecom sector in 2002, which resulted in the merger of regional telecoms into seven 'mega-regionals', reduced the number of stocks listed on the RTS and MICEX to 
approximately 230 and 130 respectively. Since then, these numbers have remained relatively stable.

However, not all listed stocks are traded regularly. Hence, the number of stocks on the RTS with trades registered on any given day has fluctuated between 20 and 60 since 2000. This compares to nearly 100 traded stocks at the peak of the 1997 bull market. The MICEX, however, has exhibited a different pattern - the number of traded stocks has been steadily increasing since early 1999.

A notable qualitative change has occurred in 2005, as the number of traded stocks on any given day has increased by around $50 \%$ to almost 90 in late 2005 . This rapid broadening of the market resurrects memories of 1997 , yet one important difference is that this is partly due to new companies going public (as opposed to the joint-stock companies forcibly created in the course of privatization). The Russian stock market saw 13 IPOs and 6 secondary offerings in 2004-2005; the combined value of deals was $\$ 880 \mathrm{mln}$ in 2004 and $\$ 5.2 \mathrm{bln}$ in 2005. It is worth noting that the largest IPO to date came not from a commodity-producing industry. The successful placement of $\$ 1.56$ bln by AFK Sistema from the telecom sector underscores investor interest in Russia's consumer economy. Other offerings coming from the food, retail, media, and metal\&mining sectors further improved the diversification opportunities for investors in Russia.

Another trend was the increasing accessibility of the Russian stock market to international investors, in particular, to large regulated institutional investors. As shown in the last panel of Fig. 3, depositary receipts (DR) are currently available for 75 Russian stocks, most of whose DR programs were launched after the 1998 crisis.

Dynamics of the trading volumes provides further evidence of a qualitative change in the structure of the Russian equity market since the 1998 crash. The dominance of quote-driven trading running through the RTS dealers is consigned to the past. Combined turnover across all trading platforms (ex OTC), which in 2004 exceeded \$200 bln, or more than 7 times the 1997 volume, is currently split between the RTS, MICEX and DRs in proportions of approximately $10 / 45 / 45$. The much greater prominence of MICEX and DR trading in comparison with the early years of the Russian stock market indicates a greater role of both domestic small investors eager to minimize transaction costs (MICEX is an order-driven trading platform) and international institutional investors. Admittedly, in recent months the RTS' share has increased somewhat on the back of higher interest in second-tier names, in which the RTS, with its broader scope of listed stocks, still holds a dominant position. 


\subsection{Risk-return trade-off}

Summary statistics of the Russian stock market are presented on a year-to-year basis in Table 1. The RTS index (RTSI), which is the most prominent index of the Russian stock market, achieved the level of 1125.6 at the end of 2005, more than an eleven-fold increase from its starting value of 100 (in dollar terms). Of the eleven calendar years between 1995 and 2005 eight ended with positive returns for the RTSI, whereas in three years - 1995, 1998 and 2000 - the index ended in the red.

That said, the reverse of these (mostly) hefty long-term returns has also been considerable, with a very high degree of volatility in the Russian stock market. Hence, the RTSI's annual high exceeded the same year's low by more than $50 \%$ in almost every single calendar year. The annualized standard deviation of the RTSI's weekly returns for the period since its start till the end of 2005 was $7.3 \%$. The good news, though, is that having peaked prior to the 1998 crisis, the market's volatility has been mostly on a downward path (see the first panel of Fig. 4). The only material deviation from this otherwise fairly steady trend was the period of attacks on Yukos. However, it seems that the shock from that event has already been fully absorbed by the market. The standard deviation of weekly returns (calculated across a rolling 1-year window) has declined from 5.1\% at the peak of the Yukos affair to the historic low of 2.8\% in December 2005.

The relationship between the RTS index and global equity indices varied a lot over time. The correlation between the RTSI and the MSCI World index went through several up and down cycles, ranging from 0.04 to 0.6 (see the second panel of Fig. 4). The RTSI's relation with the MSCI EM index was more stable, with the correlation coefficient staying most of the time between 0.4 and 0.8 . Not surprisingly, as discussed in section 4, the model including the MSCI EM index overperforms that with the MSCI World index. The difference between the two relationships was most evident in mid-1997, 2000, and end-2001, when the Russian market went along with other emerging markets counter to the developed markets' trends. At the end of 2003, the attack on Yukos led to synchronous decrease in RTSI's correlations with both global indices.

The headline index performance does not, however, tell the full story. Therefore, we examine the cross-sectional distribution of individual stock returns for each calendar year from 1996 to 2005 (see the second panel of Table 1), using the sample of all Russian stocks ever traded on the RTS and/or MICEX, or in the form of depositary receipts ${ }^{1}$. Since our dataset contains a large number of second-tier stocks, which are characterized by low liquidity and may be subject

${ }^{1}$ Only stocks with non-zero trading volumes for at least 5 days were included in the sample. Any given stock is in the sample from the date when the first trade in this stock was registered and until the last day when quotes for this stock existed on any of the exchanges. 
to sharp price movements, every year features a handful of outliers which render the mean, minimum and maximum statistics fairly uninformative. We therefore focus on those measures, which are relatively insensitive to the presence of outliers: the median return and lower and upper deciles of the sample distributions.

The median return in our sample of Russian stocks was positive in every year except 1998, while the 9 th decile return was in triple digits in each of those years. At the same time, the bottom decile return was mostly negative during the decade, the only exceptions being in 1997 and 2003, years of major rallies.

The main observation, however, is that the cross-sectional variance of stock returns in Russia is considerable. This defies the notion that Russia is a macro play, and that stock picking is of secondary importance. The fact that in almost every year the returns of the middle $80 \%$ of the stocks in our sample vary by $150 \%$ or more clearly demonstrates the importance of firmspecific risk.

A considerable proportion of the cross-sectional variance in individual stock returns is due to the variance in returns between the sectors (see the final panel of Table 1). We observe a considerable performance gap between the sectors in every year starting from 1999. Moreover, no sector has managed to remain among the market leaders (i.e. top two performers) for more than two consecutive years. This might be due to a higher role of firm- and industry-specific factors in the recent years, in contrast to the prevalence of the country risk in the early years of the market. In section 4 , we elaborate on this point.

\section{Qualitative analysis of the risk factors driving Russian stock returns}

In this section, we review major political and economic events, which influenced investors' perception of the country risk and were reflected in stock prices. We focus on two factors: political risk and corporate governance, which were extremely important, yet hard to measure and include in the formal model of Russian stocks. Fig. 1 shows the dynamics of the RTS index together with captions for the major events.

In the first chapter of the market's history, from the launch of the RTSI in September 1995 to the resignation of President Yeltsin on 31 December 1999, the market was moved by a binary perception that Russia was headed either for a relapse into Soviet-style politics and economics, or else would break out into a functioning law-based market system. The RTSI's first months were marked by steady decline given the seeming inevitability (reinforced by the result of the Duma election in December 1995) that Gennady Zyuganov and his unreconstructed communist party would come to power. This trend was dramatically reversed in the second quarter of 1996, when 
the RTS index tripled as the prospects of Yeltsin's re-election firmed (not only keeping out the communists, but also avoiding the hardly less alarming scenario of holding on to power by setting aside the constitution and canceling elections). Investors' approach to the market in this early period as a binary country risk play is reflected in the way that all sectors went up identically in 'Yeltsin re-election' rally of 1996 in contrast to the much greater differentiation of sectoral performance as investor perceptions matured over the years (see the final panel of Table 1 capturing this contrast).

That outcome was the key to a widespread assumption among international investors (who then dominated market activity) that the country's transition would now be plain sailing. That illusion and its destruction in the crisis that culminated in August 1998 with the ruble devaluation and government debt default produced one of the most remarkable boom-bust cycles in the history of financial markets. The RTSI plummeted 93\% from its pre-crisis peak of 572 on 6 October 1997 to a low of 39 exactly a year later on 5 October 1998.

Although the bust was precipitated by the external shock of the Asian crisis, its root cause lay in misperception of Russia's country risk. Yeltsin's second mandate was a negative one, based on the preference of a majority of voters not to return to the Soviet past. Against the background of the deep recession and widespread hardship in the first years after the collapse of the Soviet system, the re-elected administration lacked the political capital to implement tough but essential reforms - above all a fiscal adjustment, the lack of which was the root cause of the 1998 financial crisis. This resulted in looming budget deficits and further decline in GDP.

Meanwhile, the administration's weakness was compounded by the power of the business leaders, so-called 'oligarchs', who had acquired control of prize natural resource assets in the notorious 'shares-for-loans' privatization auctions in late 1995 (see Freeland, 2000, Hoffman, 2002, and Goldman, 2003). The financing of Yeltsin's re-election campaign was only the first step in a 'privatization of the state', with many senior officials and legislators effectively on the payroll of one or another of the leading business groups (see Frye, 2004, Guriev and Rachinsky, 2005, Hoff and Stiglitz, 2004, Sonin, 2003, for the analysis of political connections of big businessmen in Russia). This created a vicious circle. Beholden to big business interests, the already weak administration became even less capable of carrying out reforms - including the enforcement of better corporate governance standards. At the same time, the administration's weakness and unpopularity appeared to increase the risk of Yeltsin's successor reversing privatization and other reforms. This perceived risk of expropriation increased the incentive for the 'oligarchs' to extract cash from their companies while they could. That meant abusing minority shareholder rights in a series of scandalous dilutions, transfer pricing, and poor disclosure (see Black, Kraakman, and Tarassova, 2000, for examples of such abuses). 
Given this background, it is not surprising that the RTSI's largest one-day gain - of $16.8 \%$ - in its ten-year history took place on the day which saw the successful culmination of the operation to engineer a succession to Yeltsin, which held out the prospect of policy continuity, above all by allowing the 1990s privatizations to stand and which (as in 1996) avoided any destabilizing departure from constitutional procedures. It was 31 December 1999 when Yeltsin resigned, with the result that the Prime Minister, Vladimir Putin, became acting President and was elected three months later. However, this was the last time the market would be so decisively driven by binary political risk perception.

The pattern for the second - and still unfinished - chapter in the market's history under President Putin falls into two parts. First, it took the best part of two years for investors to recover confidence for Russian equities, even though the fundamental case for the market's eventual rerating had been laid in the first months. By the third quarter of 2000, some worrisome incidents of oligarch bashing during the previous spring had given way to a clear and positive political position - most explicitly articulated by Putin in a meeting with business leaders in the Kremlin in July that year. This was the historic compromise involving a de facto amnesty of the 1990s privatizations combined with the oligarchs being put on notice that they should not use their controversially acquired wealth to privatize the state itself.

This settlement transformed the incentives for corporate governance. The improved security of title to their assets gave the controlling owners of Russia's major companies an interest in both maximizing and protecting their wealth (including the benefits of improved reputation) by increasing their companies' market valuation. Additional support came from a thorough overhaul of basic company law (the Law on Joint Stock Companies), which entered into force in January 2002. The comprehensive amendments were designed to close out the loopholes which had been exploited by owners and managers in the late 1990s to disenfranchise minorities, especially by means of abusive share dilutions.

The company that took the lead in the move from vice to virtue on the corporate governance front was the oil company Yukos. Once a nightmare for the minority shareholders, since 2000 it had been setting new standards in reporting, auditing, and dividend policy. As a result, Yukos' stock price increased over two years by more than 12 times making it the secondlargest Russian company at that time. Other Russian companies improving corporate governance also benefited in terms of market capitalization (e.g., Black, Love, and Rachinsky, 2005).

Meanwhile, the other foundations for a market re-rating were soon laid. Political stability was assured by Putin's legitimacy and popularity established by the parliamentary and presidential elections of December 1999-March 2000. The twin keys to macroeconomic stability, a recovering oil price and prudent fiscal policy, were similarly well in evidence by mid-2000 - as 
was the new administration's readiness and ability to pursue serious structural reforms, starting with the introduction of a flat $13 \%$ income tax and other radical tax reforms.

Yet it was only in the fourth quarter of 2001 that the re-rating got underway - triggered by the external shock of 9/11 and its geopolitical consequences, when with the help of some adroit diplomatic footwork from President Putin, Russia emerged as an ally of the US and other elite countries in the new 'war against terror'. That perception led to the most spectacular phase of the equity market's re-rating as the RTSI rallied from 180 to 782 - an increase of $334 \%$ - in just thirty months (October 2001-April 2004).

Since then, there was one major interruption in the market's progress - the Yukos affair. In the second half of 2003, Yukos' top managers and major owners, Mikhail Khodorkovsky and Platon Lebedev, were arrested with the charges of tax evasion and embezzlement. The company was put under scrutiny and received numerous back-dated tax charges eventually amounting to \$27.5 bln. Even the forced sale of Yukos' major production unit (Yuganskneftegaz) in December 2004 did not help the company to put off the danger of bankruptcy. Apparently, investors interpreted Yukos events as a signal about the toughening of the government policy towards the business community. The political risk appeared especially high for non-transparent private companies, oil companies, firms privatized via the ill-famous loans-for-shares auctions, and, surprisingly, transparent state-owned companies, judging by sensitivity of their stock prices to Yukos events (Goriaev and Sonin, 2005). The Yukos saga along with similar cases of disproportionate back-dated tax charges against other companies (e.g., Vimpelcom and Sibneft) triggered several double-digit corrections in the market. The most serious of them in April-July 2004 dragged the RTSI down by 33\%. However, even after the last correction in December 2004, the RTS index was still 6\% above its level when the whole affair began.

This story suggests that just as it took time for the Putin administration to overcome investors' initial scepticism about the prospects for Russia's transition after the painful 1990s, once a track record had been established, the market was equally reluctant to believe that Putin would be ready to throw away his achievements - including improving the security of property rights - for the sake of arbitrary asset grabs. Apparently, in the end, investors believed that the Yukos affair would not lead to wide-scale expropriation of companies by the state. The decline in the perceived political risk led to another impressive rally in the second half of 2005.

Moving from particular turning points to the full picture of the RTSI's performance over its first decade, this may also be taken as a fair reflection of Russia's overall post-Soviet progress in the sense that despite all the shocks and setbacks, the transition has stayed on the rails. The key practical effects of transition progress from the equity market perspective are first the creation of value in companies in the commodity-exporting sectors which dominate the economy, and 
secondly the emergence of new businesses - especially in consumer-oriented and service sectors - which by definition could not exist under Soviet central planning and which have begun to tap the public capital markets.

\section{Quantitative analysis of the risk factors driving Russian stock returns}

What drives Russian equity prices? Ultimately, the key determinants of the Russian stock market's long-run trends are economic growth and further re-rating of country risk and firmspecific risks by the investment community. However, short-run movements in Russian stocks are to a considerable extent induced by fluctuations in other financial markets, both domestic and international. Those which are widely considered as being of primary importance include global equity markets (especially, emerging markets), commodity markets (in particular, crude oil), FX and interest rate trends, and the domestic money market. In this section, we perform a quantitative assessment of whether these are systematic risks driving Russian stock returns.

\subsection{Data and methodology}

We consider weekly data on Russian equity indices and risk factors over the period from September 1995 to December 2005. The RTS index is employed as the local market index. ${ }^{2}$ The UFG oil, (electric) utilities, metals, wireline, wireless, and consumer goods indices as well as Gazprom and Sberbank stocks represent corresponding sectors of the Russian economy. ${ }^{3}$ The one-month Treasury bill rate is used as a risk-free rate. The MSCI World and MSCI Emerging Markets (EM) equity indices indicate global equity risks. The oil price measured as the Brent one-month generic future proxies for the commodity risk, whereas one-year LIBOR accounts for global interest rate risk. The exchange rates of ruble to dollar and dollar to Euro measure currency risk, whereas domestic (money market) liquidity is indicated by the Russian banks' excess reserves (more precisely, the sum of their correspondent accounts and time deposits at the

${ }^{2}$ The results remain the same is we use the MSCI Russia equity index, which is highly correlated with the RTS index.

${ }^{3}$ The oil index is dominated by such companies as LUKoil, Surgutneftegaz, Tatneft, Sibneft, and Yukos. The utilities index includes RAO UES and its subsidiaries, the metals index is dominated by Norilsk Nikel, Severstal and Mechel. The wireline index includes Rostelecom and regional telecoms, whereas the wireless index (since January 1998) covers private mobile operators such as Vimpelcom and MTS. The consumer goods index (since January 2000) includes the beverages producer Wimm-Bill-Dann and retailers such as Pyaterochka. Gazprom and Sberbank are the only traded companies in the gas and banking sectors. 
Bank of Russia). ${ }^{4}$ All of these weekly data are based on Friday close value, except for the last variable, for which the weekly average is used.

We construct weekly series of log-returns on the stock indices (in dollars) and risk factor proxies, which are found to be $\mathrm{I}(0)$ using the conventional unit root testing procedures. Table 2 reports summary statistics of the risk factors for the whole sample period and two subperiods (before and after end-1999). During this period, the MSCI world index dominated by the developed markets grew faster than the MSCI EM index (5.9\% and 3.9\% p.a.) and had lower volatility (14.6\% and $20.6 \%$ p.a., respectively). However, this difference is mostly due to the bull market in the US at the end of 1990s, which was accompanied by rising global interest rates and strong dollar. In the first half of 2000s, the developed markets became bearish, interest rates were declining, dollar was weakening, and the oil price growth accelerated (from $9.5 \%$ to $14 \%$ p.a.). In Russia, the nominal exchange rate of ruble to dollar stopped rising and growth in the excess banks' reserves slowed down after 1999. The correlations between the risk factors were relatively low, except for that between the MSCI World and MSCI EM indices (0.722).

The magnitude of change in Russia's political and economic situation over the past decade, as well as the evolution of the institutional framework discussed in the previous sections, suggest that systematic risks of Russian stocks did not stay constant over time. Indeed, the preliminary analysis of the Russian stock market in section 2.2 shows that the volatility as well as links with international markets varied considerably over time. Therefore, similarly to Anatolyev (2005), we use the methodology of linear time series regressions of the Russian equity indices on risk factors over a one-year rolling data window, which moves in time along the whole sample period. This approach enables us to capture the changes in the nature of the studied relationships over time in a simple, yet robust manner. ${ }^{5}$ The estimation method is ordinary least squares with the standard White adjustment for heteroscedasticity. We evaluate the models by the significance of the factor coefficients and by $\mathrm{R}^{2}$.

\subsection{Single-factor model}

Our basic single-factor model is based on the world CAPM:

$$
\mathrm{R}_{\mathrm{t}}-\mathrm{R}_{\mathrm{F}, \mathrm{t}}=\mathrm{a}+\mathrm{b}\left(\mathrm{R}_{\mathrm{M}, \mathrm{t}}-\mathrm{R}_{\mathrm{F}, \mathrm{t}}\right)+\mathrm{e}_{\mathrm{t}}
$$

${ }^{4}$ We have tried a number of other variables including the EMBI spread between yields on Russian government Eurobonds and US Treasury bonds proxying for Russia's country risk, trading volumes indicating liquidity, and alternative measures of the oil price, interest and exchange rates. They were inferior to the selected measures based on their performance in the regressions.

${ }^{5}$ An alternative approach would be to use the conditional version of an asset pricing model. However, it is hard to find appropriate instruments at a given frequency. 
where $R_{t}$ is the Russian equity index return, $R_{M, t}$ and $R_{F, t}$ are the global market index return and the risk-free rate, respectively, and $e_{t}$ is the error term. Assuming market integration at a global or at a regional level, we use either the MSCI World or the MSCI EM as a global market index.

Fig. 5 presents evolution of beta coefficients and $\mathrm{R}^{2}$ for the RTS index. On average, the RTSI's beta with respect to the MSCI World index was 1.3 , being significant in $70 \%$ of the regressions and explaining $16 \%$ of the RTSI's variation. However, the model failed to explain the RTSI's dynamics at the times of the presidential elections in 1996, Asian crisis in 1997, burst of the dotcom bubble in 2000, and Yukos affair at the end of 2003, when beta was insignificant and $\mathrm{R}^{2}$ was close to zero. The sensitivity of the Russian stock market to the global equity risk seems to have decreased over time (from 2.04 to 0.9 before and after 1999), yet this relationship has become more stable (with beta being significant in approximately $75 \%$ of the regressions after 1999 , compared to $63 \%$ before 1999 ).

The model with the MSCI EM index showed better results, with the RTSI's beta being significant in $89 \%$ of the regressions and $\mathrm{R}^{2}$ equal to 0.26 . Most of the time, beta was on general downward trend from the peak during the Asian crisis to round 1 in 2005. The only exception is the period of the attack on Yukos, when beta became insignificant. This evidence suggests the Russian stock market is only partially integrated in the global markets, with the strongest relation being with other emerging markets. Therefore, from now on we use only the MSCI EM as the global market index in our models.

The first panel of table 3 reports results of model (1) for the RTS index and industry indices aggregated for the whole sample period (September 1996 to December 2005) and two subperiods (before and after end-1999). Our analysis reveals a considerable variation in sensitivity to the global market risk not only in the time dimension, but also in the cross-section. The utilities and telecom (wireline and wireless) sectors have the highest betas with respect to the MSCI EM index (1.45 and 1.31, respectively), closely followed by the metals and oil industries (1.25 and 1.21, respectively). The consumer goods sector driven by rapidly growing consumer demand in Russia in recent years appears to be the least sensitive to the global trends, with the lowest MSCI EM beta of 0.38 and lowest percentage of regressions with significant betas (37\% after 1999). Most industries (especially Gazprom, wireless, and Sberbank) became more closely related to the emerging markets judging by the rise in $\mathrm{R}^{2}$ and in the percentage of regressions with significant betas after 1999. However, the reverse was true for the oil companies (and, as a result, for the RTS index), which is probably due to their rising sensitivity to other risk factors, in particular, to the oil price, as discussed in the next section.

The average $\mathrm{R}^{2}$ across the industry indices, which may be interpreted according to Morck, Yeung, and Yu (2000) as a measure of stock market synchronicity, stayed on the same level 
(0.17) in the two subperiods. The dynamics of this measure within the subperiods did not reveal any clear pattern.

To summarize, these results demonstrate a strong relation between Russian stocks and emerging markets. However, even the single-factor model with the MSCI EM index fails to explain more than $30 \%$ of the total RTSI's variation, and even less so for the sector indices. Therefore, in the next section, we evaluate a multi-factor model, which includes a number of additional global and local risk factors along with the MSCI EM index.

\subsection{Multi-factor model}

The extended model is as follows:

$$
\begin{aligned}
\mathrm{R}_{\mathrm{t}}-\mathrm{R}_{\mathrm{F}, \mathrm{t}}= & \mathrm{a}+\mathrm{b}_{1}\left(\mathrm{R}_{\mathrm{M}, \mathrm{t}}-\mathrm{R}_{\mathrm{F}, \mathrm{t}}\right)+\mathrm{b}_{2} \Delta \ln \left(\mathrm{Oil}_{\mathrm{t}}\right)+\mathrm{b}_{3} \Delta \ln \left(\mathrm{LIBOR}_{\mathrm{t}}\right)+\mathrm{b}_{4} \Delta \ln \left(\mathrm{RUB} / \mathrm{USD}_{\mathrm{t}}\right) \\
& +\mathrm{b}_{5} \Delta \ln \left(\mathrm{USD} / \mathrm{EUR}_{\mathrm{t}}\right)+\mathrm{b}_{6} \Delta \ln \left(\text { Liquidity }_{\mathrm{t}}\right)+\mathrm{e}_{\mathrm{t}},
\end{aligned}
$$

where the notation is self-explanatory. Since the market before 1999 was very volatile and mainly driven by the crisis events and since data on the USD/EUR and domestic liquidity factors are missing for the first subperiod, we estimate the model (2) only for the second subperiod (20002005).

The second panel of Table 3 reports the aggregated results of model (2) for the RTS index and industry indices; Fig. 6 presents dynamics of the factor coefficients and $\mathrm{R}^{2}$ over time. The additional risk factors make a significant contribution to explaining the Russian stock returns, as the null hypothesis that all of the corresponding coefficients be equal to zero is rejected at $5 \%$ level in $95 \%$ of the regressions for the RTS index and not less than $67 \%$ of the regressions for the sector indices. The average $\mathrm{R}^{2}$ increases from 0.24 to 0.36 for the RTSI and by similar order of the magnitude for the industry indices.

The MSCI EM index remains the primary risk factor for the RTSI and sector indices, as beta's significance and dynamics are hardly affected by the inclusion of the additional factors. Contrary to common perception, the sensitivity of the Russian stock market to the oil price turns out to be fairly modest; the corresponding coefficient for the RTSI is significantly positive only in $29 \%$ of the regressions, mostly during the last 3 years. This result does not deny the important role that oil price plays for the Russian economy. Probably, its influence on the stock market is expressed via gradual reassessment of expectations about the long-term oil price level, whereas interim oil price volatility is only of secondary importance relative to emerging markets' fluctuations. As expected, the most sensitive sectors are the oil and gas industries.

The ruble and Euro appreciation against dollar contributed to the growth of the RTS index, with the corresponding coefficients being significant in $21 \%$ and $34 \%$ of the regressions, respectively. The impact of the RUB/USD rate was most evident in 2000 and 2004, whereas the 
USD/EUR rate influenced the market mostly in 2001 and 2005. The largest benefit seemed to be for exporters of the natural resources such as Gazprom, oil and metals companies. Surprisingly, dynamics of the global interest rates had hardly any impact on Russian stocks; probably, it had already been compounded to other risk factors.

The influence of the banking system's excess cash reserves on the stock market has been historically limited and became evident only in 2005. Apparently, the abnormally high liquidity in the Russian money market was one of the primary drivers of the latest stock market rally in the second half of 2005 .

Overall, these results show that systematic risk factors currently play a greater role than in the past, when the country risk and individual factors were predominant. The confidence bands have been narrowing over time and the multi-factor model could explain as much as half of the total RTSI's variation in the most recent year, after the market had absorbed the effects of the Yukos affair.

\section{Conclusion}

The evolution of the Russian stock market over the first decade of its modern history can be judged as relative success. The market has shown tremendous growth in total capitalization, the number of stocks, and trading volumes, even though a number of structural deficiencies (e.g., high concentration and volatility) still remain. Analyzing the driving forces behind Russian stock returns, we document a significant role of corporate governance, political risk, and macroeconomic risk factors, such as emerging markets performance, oil prices, and exchange rates, whose relative importance varied a lot over time. During the last years, the Russian stock market has become more sensitive to macroeconomic factors, which had often been overshadowed by corporate governance scandals or political risk before.

The modern history of the Russian stock market can teach a number of lessons to investors. The first lesson is a high sensitivity of an emerging market to the political events, which can ruin the prospects of its growth or bring the fortune depending on the chosen course. Secondly, traditional risk factors become important only after a certain threshold on the level of corporate governance risk is passed. Finally, the market dynamics may be very sensitive not only to the actual country or firm-specific risk, but also to investors' perception of that risk, which might lead to under- or overreaction to certain events. Technically, these considerations imply that static models may not perform properly, and one should use dynamic models with a flexible set of risk factors to describe a highly volatile stock market environment. 


\section{References}

Anatolyev, S., 2005, A ten-year retrospection of the behavior of Russian stock returns, working paper, New Economic School.

Barry, C.B., Golgreyer, E., Lockwood, L., Rodriguez, M., 2002, Robustness of size and value effects in emerging equity markets, 1985-2000, Emerging Markets Review 3, 1-30.

Bekaert, G., Harvey, C., 1997, Emerging equity market volatility, Journal of Financial Economics 43, 29-77.

Black, B., Kraakman, R., Tarassova, A., 2000, Russian privatization and corporate governance: what went wrong? Stanford Law Review, 52, 1731-1808.

Black, B., Love, I., Rachinsky, A., 2005, Corporate governance and firms' market values: Time series evidence from Russia, McCombs research paper FIN-05-05.

Claessens, S., Djankov, S., Klingebiel, D., 2000, Stock markets in transition economies, The World Bank Financial Sector Discussion Paper No. 5.

De Jong, F., de Roon, F.A., 2005, Time-varying market integration and expected returns in emerging markets, Journal of Financial Economics 78, 583-613.

Fama, E.F., French, K.R., 1998, Value versus growth: The international evidence, Journal of Finance 53(6), 1975-1999.

Fedorov, P., Sarkissian, S., 2000, Cross-sectional variations in the degree of global integration: The case of Russian equities, Journal of International Financial Markets, Institutions and Money $102,131-150$.

Freeland, C., 2000, Sale of the Century, Crown Business, New York.

Frye, T., 2004, Credible commitment and property rights: Evidence from Russia, American Political Science Review, August 2004.

Garcia, R., Ghysels, E., 1998, Structural change and asset pricing in emerging markets, Journal of International Money and Finance 17, 455-473.

Goldman, M., 2003, The Piratization of Russia: Russian Reform Goes Awry, Rutledge.

Goriaev, A., 2004, Risk factors in the Russian stock market, working paper, New Economic School.

Goriaev, A., Sonin, K., 2005, Is political risk company-specific? The market side of the Yukos affair, working paper, New Economic School.

Guriev, S., Rachinsky, A., 2005, The role of oligarchs in Russian capitalism, Journal of Economic Perspectives 19(1), 131-150.

Hall, S., and Urga, G., 2002, Testing for ongoing efficiency in the Russian stock market, working paper, Imperial College and City University Business School.

Hanousek, J., Filer, R.K., 2000, The relationship between economic factors and equity markets in Central Europe, Economics of Transition, 8 (3), 623-638.

Harvey, C., 1995, Predictable risk and return in emerging markets, Review of Financial Studies 8, 773-816.

Hoff, K., Stiglitz, J.E., 2004, After the Big Bang? Obstacles to the emergence of the rule of law in post-communist societies, American Economic Review 94(3), 753-763.

Hoffman, D., 2002, The Oligarchs: Wealth and Power in the New Russia, Public Affairs, New York. 
King, R.G., Levine, R., 1993, Finance and growth: Schumpeter might be right, The Quarterly Journal of Economics 108 (3), 717-737.

La Porta, R., Lopez-de-Silanes, F., Shleifer, A., Vishny, R., 1997, Legal determinants of external finance, Journal of Finance 52, 1131-1150.

Levine, R., 1999, Law, finance, and economic growth, Journal of Financial Intermediation 8, 835 .

Lucey, B.M., Voronkova, S., 2005, Russian equity market linkages before and after the 1998 crisis: Evidence from time-varying and stochastic cointegration tests, BOFIT working paper.

Mateus, T., 2004, The risk and predictability of equity returns of the EU accession countries, Emerging Markets Review 5, 241-266.

Morck, R., Yeung, B., Yu, W., 2000, The information content of stock markets: Why do emerging markets have synchronous stock price movements? Journal of Financial Economics 58, 215-260.

Rajan, R.G., Zingales, L., 2003a, Financial dependence and growth, American Economic Review $88,559-586$.

Rajan, R.G., Zingales, L., 2003b, The great reversals: The politics of financial development in the twentieth century, Journal of Financial Economics 69 (1), 5-50.

Rouwenhorst, K.G., 1999, Local return factors and turnover in emerging stock markets, Journal of Finance 54(4), 1439-1464.

Schumpeter, J.A., 1911, A Theory of Economic Development, Cambridge, MA, Harvard University Press.

Sokalska, 2001, What drives equity returns in Central and Eastern Europe, working paper, Warsaw School of Economics.

Sonin, K., 2003, Why the rich may favor poor protection of property rights, Journal of Comparative Economics, 31 (4), 715-731.

Van der Hart, J., Slagter, E., van Dijk, D., 2003, Stock selection strategies in emerging markets, Journal of Empirical Finance 10, 105-132. 
Table 1

Annual summary statistics of the RTS Index

\begin{tabular}{|c|c|c|c|c|c|c|c|c|c|c|c|}
\hline & 1995 & 1996 & 1997 & 1998 & 1999 & 2000 & 2001 & 2002 & 2003 & 2004 & 2005 \\
\hline End of period & 82.92 & 200.5 & 396.86 & 58.93 & 175.36 & 143.29 & 260.05 & 359.07 & 567.25 & 614.11 & 1125.6 \\
\hline Change & $-17 \%$ & $142 \%$ & $98 \%$ & $-85 \%$ & $197 \%$ & $-18 \%$ & $81 \%$ & $38 \%$ & $58 \%$ & $8 \%$ & $83 \%$ \\
\hline Average & 81.18 & 142.15 & 393.96 & 180.81 & 97.43 & 194.6 & 195.04 & 345.28 & 469.81 & 624.66 & 803.58 \\
\hline Change & $\mathrm{n} / \mathrm{a}$ & $75 \%$ & $177 \%$ & $-54 \%$ & $-46 \%$ & $100 \%$ & $0 \%$ & $77 \%$ & $36 \%$ & $33 \%$ & $29 \%$ \\
\hline Min & 68.09 & 66.69 & 213.38 & 38.53 & 54.49 & 132.07 & 131.02 & 267.70 & 336.08 & 518.15 & 591.67 \\
\hline Max & 101.3 & 227.79 & 571.66 & 411.61 & 175.26 & 245.49 & 260.05 & 425.43 & 643.3 & 781.55 & 1128.51 \\
\hline Difference & $49 \%$ & $242 \%$ & $168 \%$ & $968 \%$ & $222 \%$ & $86 \%$ & $98 \%$ & $59 \%$ & $91 \%$ & $51 \%$ & $91 \%$ \\
\hline
\end{tabular}

Annual returns of Russian stocks

\begin{tabular}{|c|c|c|c|c|c|c|c|c|c|c|}
\hline & 1996 & 1997 & 1998 & 1999 & 2000 & 2001 & 2002 & 2003 & 2004 & 2005 \\
\hline Mean & 432.7 & 162.3 & -74.8 & 105.1 & 113.2 & 104.1 & 55 & 124.2 & 133.5 & 70.3 \\
\hline Median & 69.2 & 94.6 & -82.3 & 7.2 & 14.9 & 62.9 & 37 & 88.1 & 35.5 & 48.2 \\
\hline Min & -83.5 & -44.2 & -99.8 & -98 & -99.7 & -98 & -86.6 & -92.9 & -95 & -82.1 \\
\hline Max & 16001.3 & 1249.3 & 19.2 & 2350.5 & 3310.0 & 1877.9 & 1587.5 & 1172.3 & 17623.6 & 813.9 \\
\hline 1st decile & -41.9 & 12.7 & -96.2 & -78.9 & -66.3 & -42.4 & -21.7 & 6.9 & -14.5 & -19.2 \\
\hline 9th decile & 360.5 & 391.6 & -45.5 & 373.3 & 258.9 & 249.5 & 135.5 & 262.3 & 130.6 & 149.3 \\
\hline \# stocks & 50 & 84 & 255 & 184 & 250 & 286 & 313 & 219 & 212 & 228 \\
\hline
\end{tabular}

Annual returns of Russian sectoral indices

\begin{tabular}{lrrrrrrrrrrr}
\hline & 1995 & 1996 & 1997 & 1998 & 1999 & 2000 & 2001 & 2002 & 2003 & 2004 & 2005 \\
\hline Oil & $-14.8 \%$ & $294.5 \%$ & $9.5 \%$ & $-80.9 \%$ & $287.1 \%$ & $-6.4 \%$ & $86.1 \%$ & $37.0 \%$ & $51.5 \%$ & $-22.9 \%$ & $91.9 \%$ \\
Gazprom & $\mathrm{n} / \mathrm{a}$ & $401.4 \%$ & $174.6 \%$ & $-89.3 \%$ & $220.4 \%$ & $-10.6 \%$ & $94.5 \%$ & $31.2 \%$ & $91.1 \%$ & $84.6 \%$ & $219.2 \%$ \\
Utilities & $-90.7 \%$ & $309.7 \%$ & $42.3 \%$ & $-87.2 \%$ & $347.3 \%$ & $-40.3 \%$ & $90.2 \%$ & $-22.5 \%$ & $116.3 \%$ & $12.8 \%$ & $49.7 \%$ \\
Metals & $-21.4 \%$ & $11.7 \%$ & $-0.1 \%$ & $-88.7 \%$ & $964.8 \%$ & $33.4 \%$ & $123.4 \%$ & $26.9 \%$ & $183.3 \%$ & $-16.8 \%$ & $44.9 \%$ \\
Wireline & $1.0 \%$ & $208.6 \%$ & $1.5 \%$ & $-76.3 \%$ & $449.1 \%$ & $-47.9 \%$ & $4.7 \%$ & $17.9 \%$ & $91.6 \%$ & $-6.3 \%$ & $34.6 \%$ \\
Wireless & $\mathrm{n} / \mathrm{a}$ & $\mathrm{n} / \mathrm{a}$ & $\mathrm{n} / \mathrm{a}$ & $-2.4 \%$ & $228.1 \%$ & $-39.4 \%$ & $43.9 \%$ & $16.9 \%$ & $134.9 \%$ & $42.6 \%$ & $24.2 \%$ \\
Consumer & & & & & & & & & & & \\
Goods & $\mathrm{n} / \mathrm{a}$ & $\mathrm{n} / \mathrm{a}$ & $\mathrm{n} / \mathrm{a}$ & $\mathrm{n} / \mathrm{a}$ & $\mathrm{n} / \mathrm{a}$ & $8.7 \%$ & $134.6 \%$ & $4.6 \%$ & $6.6 \%$ & $63.2 \%$ & $77.5 \%$ \\
Sberbank & $\mathrm{n} / \mathrm{a}$ & $\mathrm{n} / \mathrm{a}$ & $\mathrm{n} / \mathrm{a}$ & $-94.6 \%$ & $386.2 \%$ & $-47.5 \%$ & $190.0 \%$ & $157.6 \%$ & $50.4 \%$ & $69.0 \%$ & $233.0 \%$ \\
\hline
\end{tabular}

Source: UFG Research estimates. 
Table 2

Summary statistics of the risk factors

\begin{tabular}{lrrrrrr}
\hline & \multicolumn{2}{c}{$1995-2005$} & \multicolumn{2}{c}{$1995-1999$} & \multicolumn{2}{c}{$2000-2005$} \\
& Mean & St. dev. & Mean & St. dev. & Mean & St. dev. \\
\hline MSCI World & $5.9 \%$ & $14.6 \%$ & $16.7 \%$ & $13.4 \%$ & $-1.9 \%$ & $15.4 \%$ \\
MSCI EM & $3.9 \%$ & $20.6 \%$ & $0.8 \%$ & $23.2 \%$ & $6.2 \%$ & $18.6 \%$ \\
Oil & $12.1 \%$ & $34.3 \%$ & $9.5 \%$ & $31.7 \%$ & $14.0 \%$ & $36.1 \%$ \\
LIBOR & $-1.9 \%$ & $24.8 \%$ & $2.3 \%$ & $10.8 \%$ & $-5.0 \%$ & $31.2 \%$ \\
RUB/USD & $18.1 \%$ & $20.9 \%$ & $41.7 \%$ & $31.8 \%$ & $1.1 \%$ & $3.4 \%$ \\
USD/EUR & $0.2 \%$ & $10.3 \%$ & $-15.2 \%$ & $9.3 \%$ & $2.7 \%$ & $10.4 \%$ \\
Domestic & $39.6 \%$ & $97.3 \%$ & $62.4 \%$ & $92.0 \%$ & $31.3 \%$ & $99.3 \%$ \\
liquidity & & & & & & \\
\hline
\end{tabular}

For each period, the first and second column presents mean and standard deviation of the weekly log-returns of a given risk factor. Note that the data on the dollar to Euro exchange rate and domestic liquidity start from January 1999 and October 1997, respectively. 
Table 3

Results of the single-factor model

\begin{tabular}{llrrrrrrrrr}
\hline & & RTS & oil & Gazprom & utilities & metals & wireline & wireless & consumer & Sberbank \\
\hline \multirow{2}{*}{$1996-$} & Beta & 1.24 & 1.21 & 0.75 & 1.45 & 1.25 & 1.31 & 1.31 & 0.38 & 0.97 \\
2005 & \% signif. & $89.3 \%$ & $79.2 \%$ & $48.4 \%$ & $87.0 \%$ & $87.0 \%$ & $89.1 \%$ & $89.6 \%$ & $36.9 \%$ & $80.2 \%$ \\
& R2 & 0.26 & 0.19 & 0.09 & 0.24 & 0.18 & 0.25 & 0.23 & 0.05 & 0.14 \\
\hline \multirow{2}{*}{$1996-$} & Beta & 1.74 & 1.87 & 0.57 & 1.99 & 1.52 & 1.58 & 1.57 & $\mathrm{n} / \mathrm{a}$ & 1.00 \\
1999 & \% signif. & $89.6 \%$ & $90.2 \%$ & $1.9 \%$ & $89.6 \%$ & $75.1 \%$ & $71.7 \%$ & $25.5 \%$ & $\mathrm{n} / \mathrm{a}$ & $38.6 \%$ \\
& R2 & 0.30 & 0.24 & 0.04 & 0.28 & 0.16 & 0.24 & 0.16 & $\mathrm{n} / \mathrm{a}$ & 0.10 \\
\hline \multirow{2}{*}{2000 - } & Beta & 0.97 & 0.85 & 0.84 & 1.16 & 1.09 & 1.16 & 1.26 & 0.38 & 0.96 \\
2005 & \% signif. & $89.1 \%$ & $73.2 \%$ & $71.2 \%$ & $85.6 \%$ & $93.6 \%$ & $98.7 \%$ & $100.0 \%$ & $36.9 \%$ & $93.6 \%$ \\
& R2 & 0.24 & 0.16 & 0.12 & 0.21 & 0.19 & 0.26 & 0.24 & 0.05 & 0.15 \\
\hline
\end{tabular}

Results of the multi-factor model, 2000-2005

\begin{tabular}{|c|c|c|c|c|c|c|c|c|c|c|}
\hline & & RTS & oil & Gazprom & utilities & metals & wireline & wireless & consumer & Sberbank \\
\hline \multirow[t]{2}{*}{ MSCI EM } & Coef. & 1.04 & 0.92 & 0.90 & 1.26 & 1.14 & 1.19 & 1.33 & 0.31 & 1.00 \\
\hline & $\%$ signif. & $88.5 \%$ & $77.0 \%$ & $80.8 \%$ & $85.3 \%$ & $82.7 \%$ & $99.4 \%$ & $100.0 \%$ & $42.1 \%$ & $89.1 \%$ \\
\hline \multirow[t]{2}{*}{ Oil } & Coef. & 0.09 & 0.16 & 0.06 & 0.00 & 0.02 & 0.04 & 0.09 & 0.05 & 0.00 \\
\hline & $\%$ signif. & $29.1 \%$ & $46.6 \%$ & $21.7 \%$ & $0.0 \%$ & $12.5 \%$ & $7.7 \%$ & $12.1 \%$ & $6.5 \%$ & $4.5 \%$ \\
\hline \multirow[t]{2}{*}{ LIBOR } & Coef. & 0.11 & 0.05 & 0.22 & 0.05 & 0.23 & 0.03 & 0.12 & 0.09 & -0.07 \\
\hline & $\%$ signif. & $6.1 \%$ & $2.2 \%$ & $6.1 \%$ & $3.2 \%$ & $6.4 \%$ & $1.0 \%$ & $1.6 \%$ & $11.9 \%$ & $1.6 \%$ \\
\hline \multirow[t]{2}{*}{ RUB/USD } & Coef. & -1.22 & -1.28 & -2.25 & -1.79 & -0.92 & -0.82 & -1.78 & 1.06 & -1.34 \\
\hline & $\%$ signif. & $21.4 \%$ & $14.4 \%$ & $45.4 \%$ & $9.6 \%$ & $19.8 \%$ & $14.7 \%$ & $24.9 \%$ & $6.5 \%$ & $14.7 \%$ \\
\hline \multirow[t]{2}{*}{ USD/EUR } & Coef. & -0.36 & -0.33 & -0.14 & -0.51 & -0.18 & -0.02 & -0.28 & -0.08 & -0.58 \\
\hline & $\%$ signif. & $34.5 \%$ & $22.0 \%$ & $18.8 \%$ & $25.6 \%$ & $6.1 \%$ & $25.2 \%$ & $6.4 \%$ & $1.5 \%$ & $16.3 \%$ \\
\hline \multirow{4}{*}{$\begin{array}{l}\text { Domestic } \\
\text { liquidity }\end{array}$} & Coef. & -0.01 & 0.00 & 0.02 & -0.02 & 0.00 & 0.01 & -0.01 & 0.02 & -0.01 \\
\hline & \% signif. & $3.2 \%$ & $1.9 \%$ & $1.3 \%$ & $11.2 \%$ & $0.0 \%$ & $3.2 \%$ & $0.0 \%$ & $0.4 \%$ & $0.0 \%$ \\
\hline & $\% \mathrm{~F}$ test & $94.6 \%$ & $97.8 \%$ & $70.6 \%$ & $75.7 \%$ & $93.9 \%$ & $85.9 \%$ & $69.0 \%$ & $67.8 \%$ & $68.1 \%$ \\
\hline & $\mathrm{R}^{2}$ & 0.36 & 0.30 & 0.23 & 0.29 & 0.28 & 0.34 & 0.31 & 0.14 & 0.24 \\
\hline
\end{tabular}

The factor models are estimated for the RTS index and sectoral indices using a rolling 1-year data window. In the first panel, results of the single-factor model (1) with the MSCI EM index are aggregated for the whole sample period and two subperiods, September 1996 - December 1999 and January 2000 - December 2005. For each time span, the first row is the average beta coefficient, the second row is the percentage of betas having the same sign as the average coefficient and significant at $5 \%$ level, and final row is the average $\mathrm{R}^{2}$. The second panel presents results of the multi-factor model (2) estimated during the period from January 2000 to December 2005. For each risk factor, the first row is the average coefficient, the second row is the percentage of betas having the same sign as the mean. The final two rows report the percentage of regressions where the F-test for the joint significance of the additional risk factors rejects the null at 5\% level and average $\mathrm{R}^{2}$, respectively. 


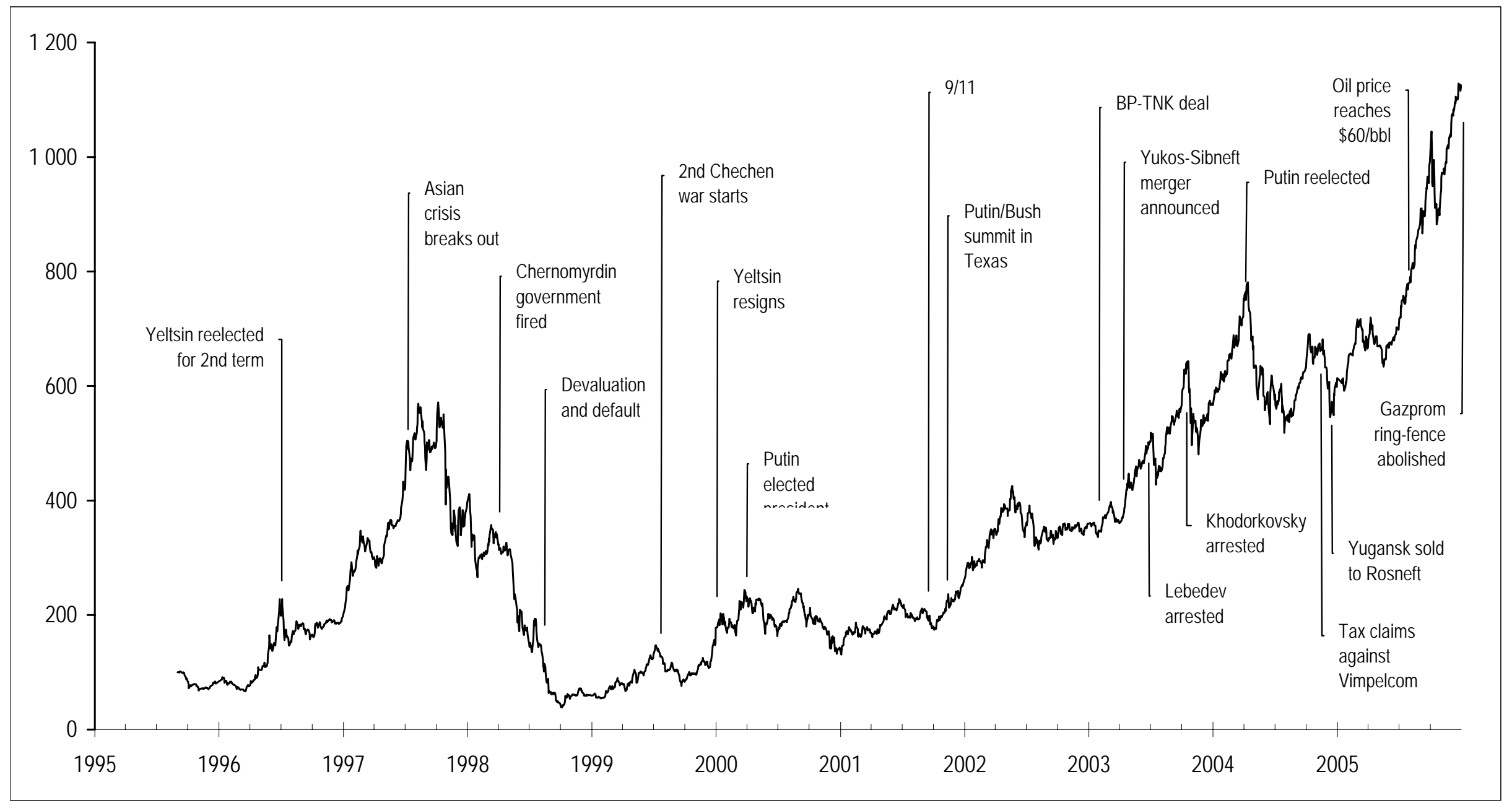

Fig. 1. Dynamics of the RTS index and key economic and political events in Russia in 1995-2005. Sources: RTS, UFG Research. 
Number of stocks listed on RTS \& MICEX

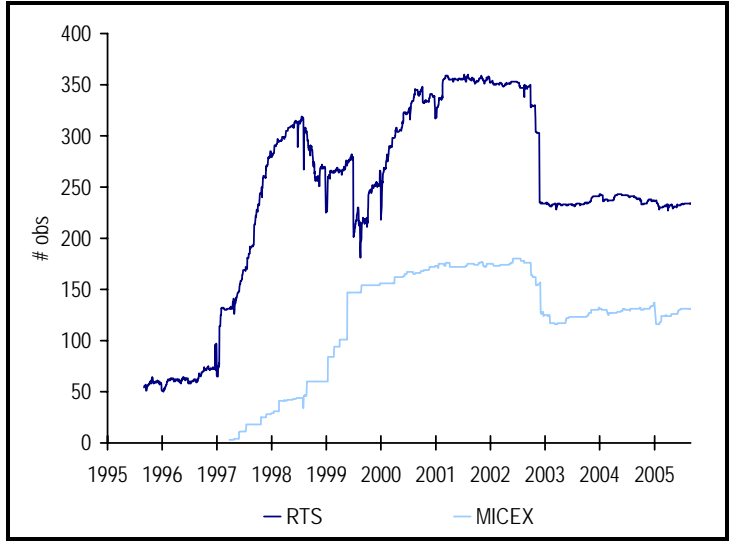

Number of stocks traded on RTS \& MICEX

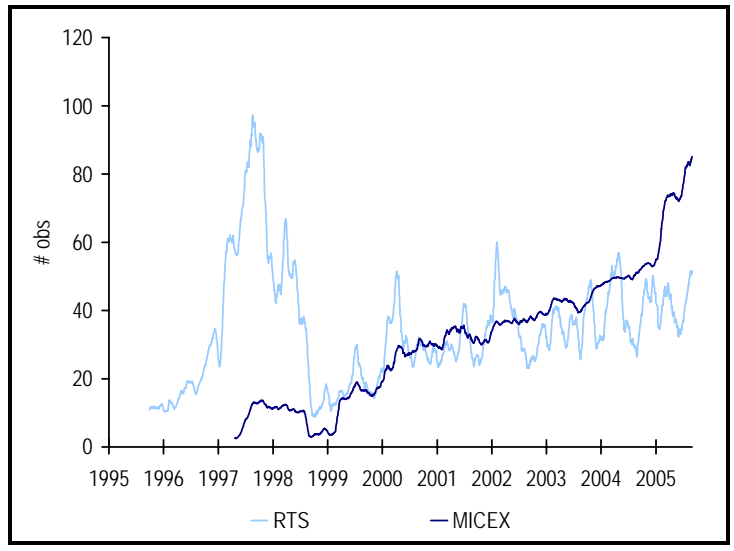

Number of stocks with depositary receipts

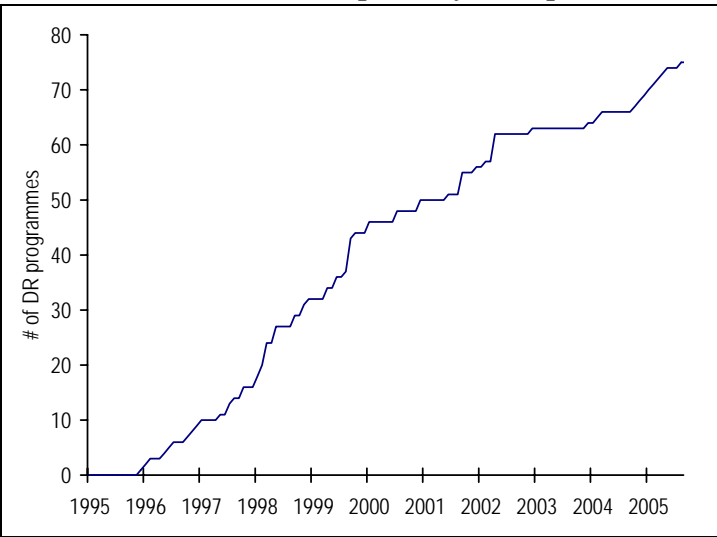

Fig. 2. The number of stocks in the Russian stock market. Sources: RTS, MICEX, BONY, UFG Research estimates. 
Monthly trading volumes, $\$$ bln

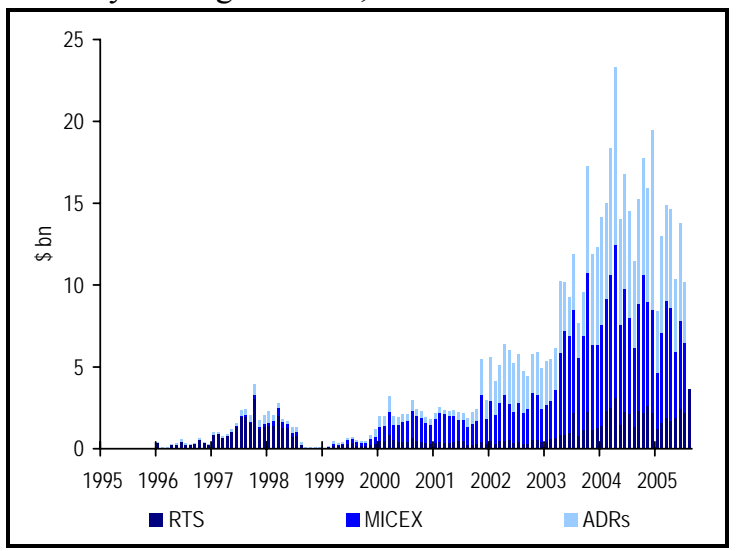

Monthly trading volumes, in \%

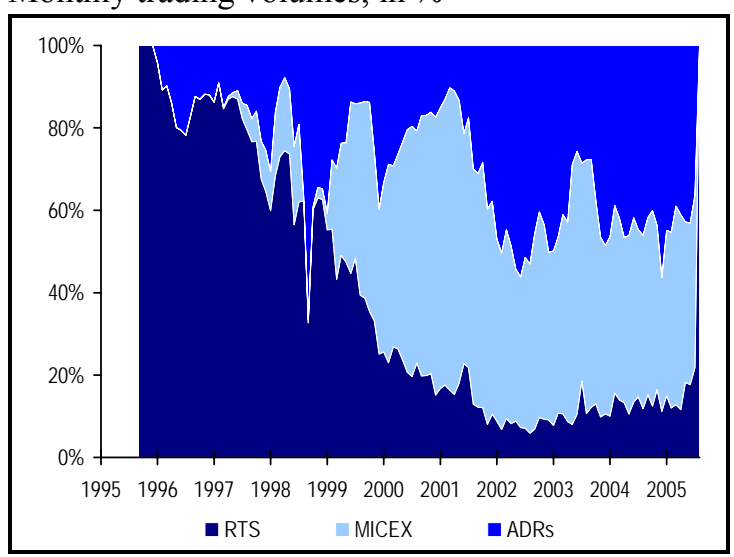

Fig. 3. Trading volumes of Russian stocks. Sources: RTS, MICEX, Bloomberg, UFG Research estimates. 
Volatility, \%

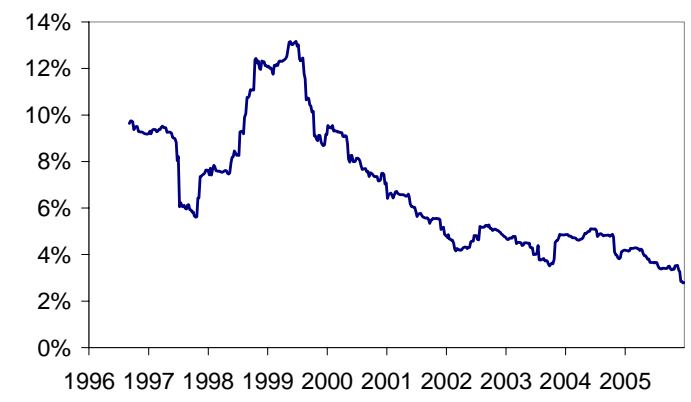

\section{Correlations}

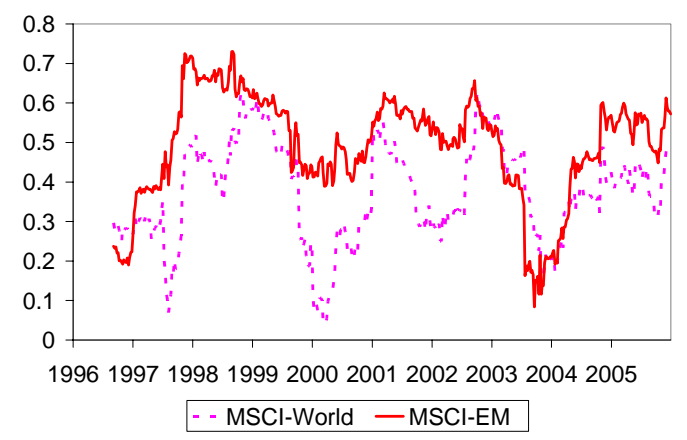

Fig. 4. Time-varying statistics of the RTS index. Endnotes: the RTS index statistics are computed using a rolling 1-year window during the period from September 1996 to December 2005; volatility is measured as annualized standard deviation of the RTSI's weekly returns. 
Panel A. Beta coefficients

The MSCI EM index

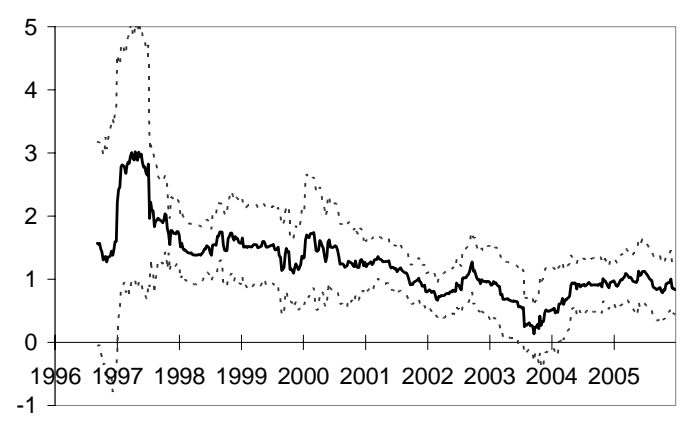

The MSCI World index

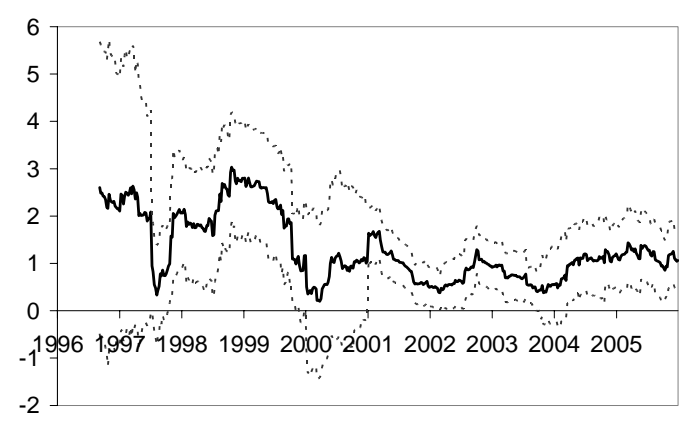

Panel B. $\mathrm{R}^{2}$

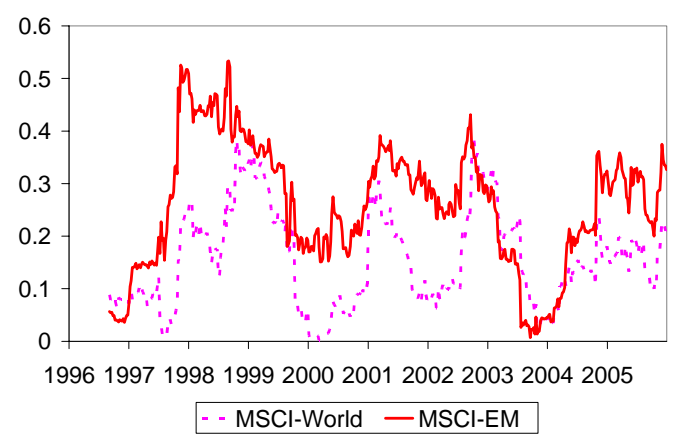

Fig. 5. Results of the single-factor model (1) for the RTS index. Endnotes: the model is estimated using a rolling 1-year data window for the period from September 1996 to December 2005. In the first panel, beta coefficient and pointwise $95 \%$ confidence interval are depicted by the bold and dotted lines, respectively. 
Panel A. Coefficients on the risk factors

\section{MSCI EM}

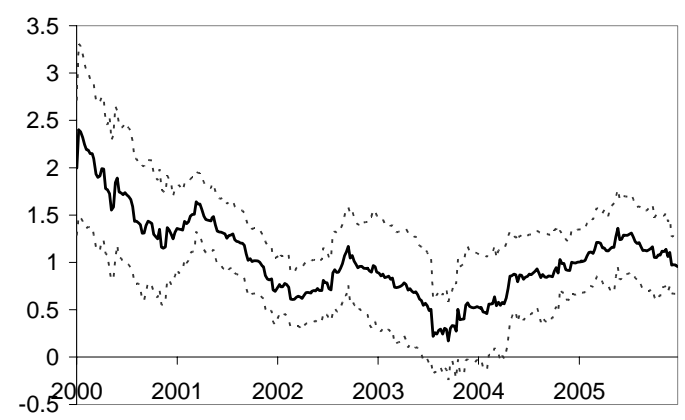

LIBOR

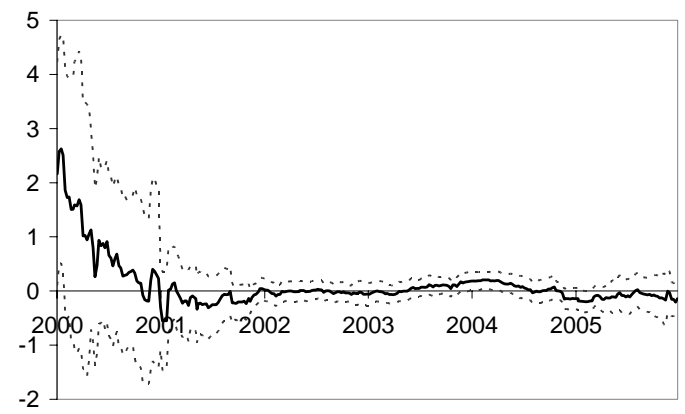

USD/EUR exchange rate

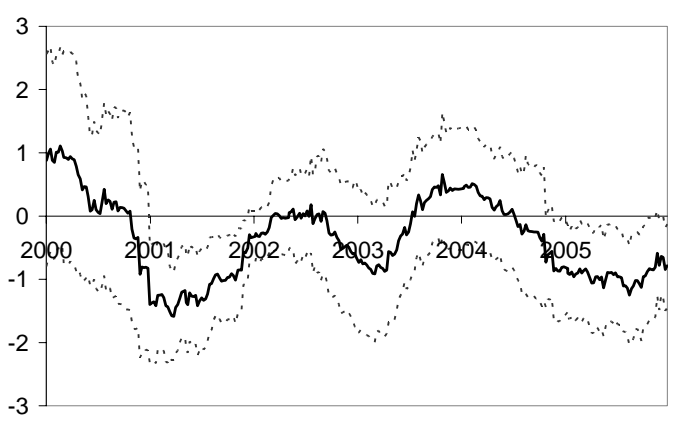

Oil price

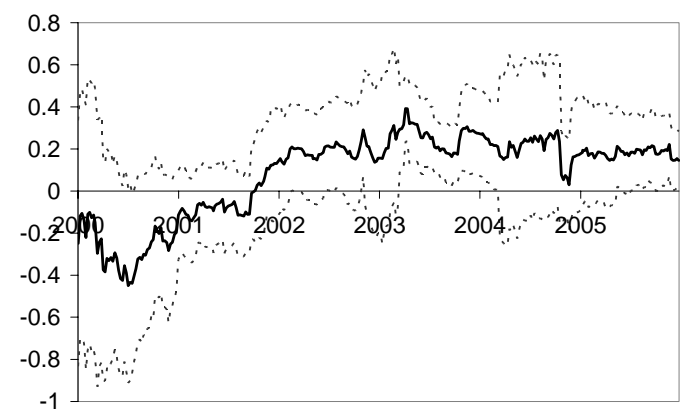

RUB/USD exchange rate

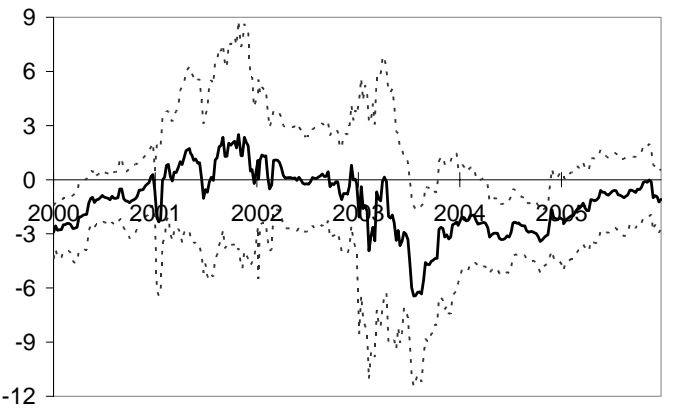

Domestic liquidity

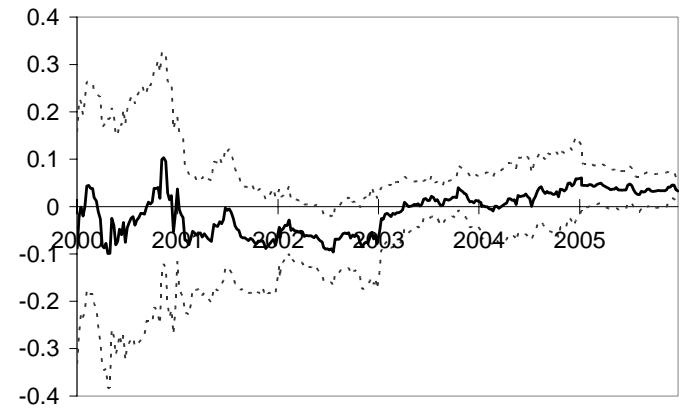

Panel B. $\mathrm{R}^{2}$

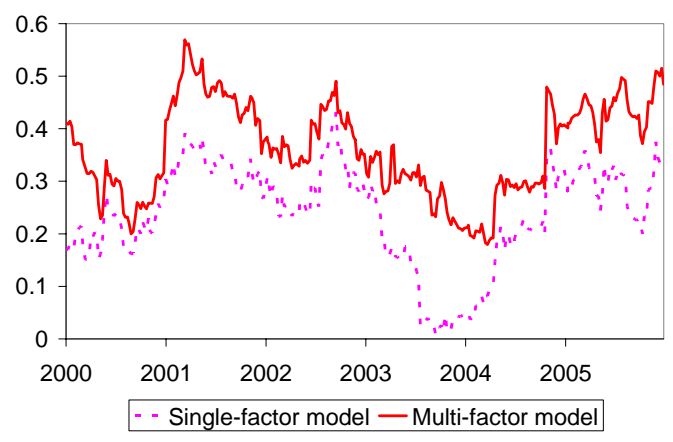

Fig. 6. Results of the multi-factor model (2) for the RTS index. Endnotes: the model is estimated using a rolling 1year data window for the period from January 2000 to December 2005. In the first panel, beta coefficient and pointwise $95 \%$ confidence interval are depicted by the bold and dotted lines, respectively. 